Article

\title{
Market-Oriented Sustainability of Sjenica Sheep Cheese
}

\author{
Jelena Filipović $\mathbb{D}$ \\ Faculty of Economics, University of Belgrade, 11000 Belgrade, Serbia; jfilipovic@ekof.bg.ac.rs
}

Received: 10 January 2019; Accepted: 28 January 2019; Published: 6 February 2019

check for updates

\begin{abstract}
This study investigated the nature and level of market-oriented sustainability of Sjenica sheep cheese, a Serbian Protected Designation of Origin (PDO)-registered product. In the analysis of the supply chain market sustainability, three theories were used: Resource dependence theory, upper echelons theory, and signaling theory. The data were collected using a stepwise research design, applying techniques of observation and in-depth and telephone interviewing. The results show that the low recognition of the PDO label among Serbian consumers and all participants in the supply chain and the lack of the presence in the markets and large packages negatively impact domestic consumers in their decisions to purchase higher amounts of Sjenica sheep cheese. Small producers lack bargaining power, whereas their perceptions hinder formation of inter-organizational arrangements. The insufficient education of big producers and distributors impede the achievement of better business results. The main challenges for the export of Sjenica sheep cheese are the inadequate certification of this food product for the European Union market, the lack of standardized production process that results in variations in the product quality, and the unawareness of the regional consumers of Sjenica sheep cheese due to insufficient communication efforts.
\end{abstract}

Keywords: food quality products; food marketing; Sjenica sheep cheese; Protected Designation of Origin

\section{Introduction}

As a concept, sustainability is becoming a focus of marketing researchers and practitioners [1]. The accounting framework of the triple bottom line appears to be mostly distinguished by its environmental component, whereas its societal and economic aspects are less represented in the research literature [2]. However, certain authors [2,3] emphasized the relevance of a broader approach, which should also include the managerial perspective, especially in the field of traditional food.

Traditional food chains variously contribute to the achievement of economic, environmental, and societal sustainability goals, by supporting: The development and sustainability of rural areas [4], protection of these areas from depopulation, significant increase in product differentiation potential for producers and processors [5,6], provision of broader and more diversified choice for consumers [3], tourism expansion of the local areas [7], and ecology [6,8].

Traditional food linked to a territory is often recognized by the designation of origin labels (DOL). There are three different DOLs in the European Union (EU): Protected Designation of Origin (PDO), Protected Geographical Indication (PGI), and Traditional Specialties Guaranteed (TSG). DOLs identify the quality differentiation attributes. DOLs can be mostly found on the products coming from the Southern EU agri-food industry [9]. The north-south divide stems from the fact that northern territories emphasize efficient production of commodities, whereas the southern countries emphasizes terroir, tradition, and artisanal production [10]. ISMEA [11] reported that the top five countries, according to the number of registered DOL food products, were: Italy (295 products), France (246), Spain (196), Greece (106), and Portugal (138). The most common group of EU products with DOL were fruits and 
vegetables, while the second largest was cheese. The majority ( $80 \%)$ of cheese products are labelled as PDOs [12] and the number of DOL cheeses continues to rise. The focus of this paper is the supply chain of Sjenica sheep cheese (SSC), a Serbian product with a PDO label.

The aim of this study was to explore the extent of sustainability of the SSC supply chain from organizational and marketing perspectives and to understand factors that hinder various actors along the SSC supply chain to achieve better market results and to increase the economic sustainability of their local territories. Despite extensive research on sustainability, the theoretical development of research from a market-oriented perspective is still in its infancy [2,13]. Building on the conclusions of previous studies $[13,14]$, the findings help bridge the theoretical gap by showcasing how three theoretical concepts (resource dependence theory (RDT), upper echelons theory (UET), and signaling theory [13]) may be employed to improve the sustainability of the PDO cheese supply chain. In terms of the effectiveness indicators of firms in the value chain in the SSC case, UET explains firms' results from the perspective of companies' top managers' characteristics, whereas RDT focuses on the bargaining power among participants in the supply chain, and signaling theory investigates whether DOLs are important to consumers, suppliers, or other stakeholders as sustainability markers. In line with the proposed theoretical framework, three main research questions were explored: The attributes of the company's management, the bargaining power of various actors in the supply chain, and the effectiveness of communications (promotional signals) aimed at consumers.

This study was based on a stepwise research design, investigating various characteristics of cheese producers and processors, complemented by fieldwork focused on the SSC commercial availability, packaging, and sizes available in retailing chains, farmers' markets, and online stores. In line with previous research [14-16], the findings of this study should help SSC stakeholders and policy makers in addressing several issues: Response to regulatory constraints and opportunities, better innovation of product offerings and business processes, increased competitive advantage, improved brand reputation, improved perception of how well the company is managed, increased margins or market share due to sustainability positioning, and cooperation with governments to promote sustainable development in the region where they operate.

\section{Theoretical Background}

Certain authors call for greater attention regarding the theoretical framework when studying sustainable chain management of traditional products [17]. A review by Connelly et al. [13] identified nine organizational theories that are considered to be the most pertinent for sustainability research in marketing: Transaction cost economics, agency theory, institutional theory, organizational ecology, resource dependence theory, resource-based view of the firm, upper echelons theory, social network theory, and signaling theory. O'Reilly et al. [18] highlighted the importance of the resource perspective for investigation of the supply chain of PDOs, whereas Krug [19] demonstrated the correlation between and the need for simultaneous observation of RDT and UET. Signaling theory is of specific relevance for understanding market-oriented sustainability, given its prominent place in the explanation of consumers' choices of products with DOLs [20-23].

RDT has been predominantly used in research to understand organization-environmental relations [24]. It predicts that organizations respond to resource dependencies by forming inter-organizational arrangements, like interlocks, alliances, joint ventures, in-sourcing arrangements, and mergers and acquisitions, which has been supported empirically [25]. In contrast with the prevailing body of the sustainability research, which appraises sustainability expenses from an economic point of view, RDT introduces the notion that organizational strategies pertaining to sustainability may be determined more by power than by profits [24]. In the marketing arena, this notion means that companies may implement sustainability initiatives if they can obtain additional freedom from dependence on others for resources or to reduce customer power [13]. This conception is primarily important for the understanding of the bargaining power of actors along the supply 
chain and their motivation for potential establishment and entering of associations to increase their power [18].

Bargaining power in the supply chain and a company's performance are highly correlated with decisions made by the dominant coalition according to UET. This theory posits that leaders' experiences, values, and personalities have significant impacts on their perception of the market circumstances, which greatly influence their choices [26,27]. A summary of previous studies [28] revealed that chief executive officer (CEO) characteristics, such as age, tenure, formal education, and prior career experience, are significantly and positively associated with a firm's future performance. Prior research [29] consistently indicated that younger executives and executives with business-related backgrounds are correlated with more innovative and/or sophisticated management systems. Empirical work examining this theory typically investigated the physical characteristics of the upper echelon, such as age and education, as observable proxies for underlying psychological constructs that shape how executives interpret environmental cues and how they respond to those cues.

As it is often difficult for buyers, suppliers, and other stakeholders to discern the extent to which a firm's products and processes are sustainable [30], different costly cues are used by companies to signal their commitment to sustainability. Unnevehr et al. [31] concluded that, in the European context, sustainable food labelling was introduced by different economic agents, such as policy makers and private food companies, with the aim of reducing the presence of asymmetric information. These labels guarantee the application of specific production conditions, promote market incentives, and highlight sustainable product attributes that may be desirable for specific niche markets. In their article, Schäufele and Hamm [32] reported that more than a third of the consumers across Europe were willing to pay a premium for wine that was produced sustainably (including being a local product). Studies based on choice experiments [21,31-35] ascertained that company efforts toward sustainability are often monitored by the consumers according to the product's origin labeling. Hence, signaling theory, from a sustainability perspective, helps our understanding of the manner in which DOLs are used to indicate the sustainability of a supply chain by various stakeholders in different regions of Europe.

\section{Case Study of Sjenica Sheep Cheese}

\subsection{Characteristics of SSC}

Even though Serbia is a Southeastern European country and is expected to share its orientation with other southern countries in terms of DO certification, the modest number of DOLs leads to an opposite conclusion. There are 71 registered products with a DOL in Serbia, encompassing 57 domestic and 14 foreign products [36]. There are no Serbian products in any of the three DO categories registered in the EU [37]. Of the 57 domestic-registered PDO products, 12 belong to the cheese category, constituting, along with meat, the most represented food category. Sjenica cheese is produced either from cow or sheep milk and, accordingly, two types of this cheese have been labelled. The registered trademark [38] is presented in Figure 1a, the stylized heads of the sheep and the rams of the typical race for Sjenica (Figure 1b)—recognizable by the expressive streaks on the snout, eyes, and ears.

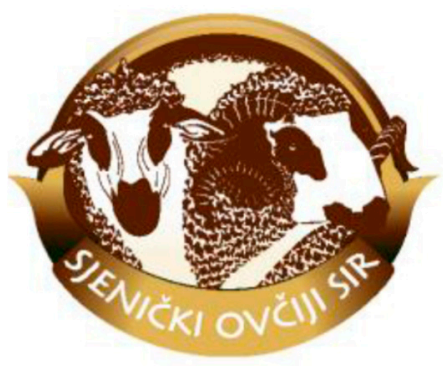

(a)

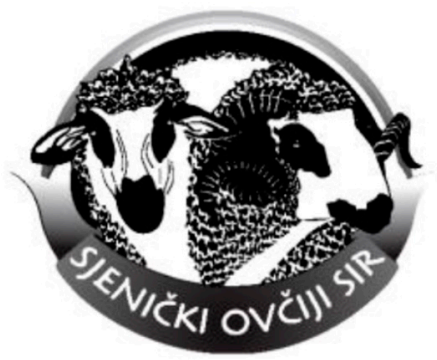

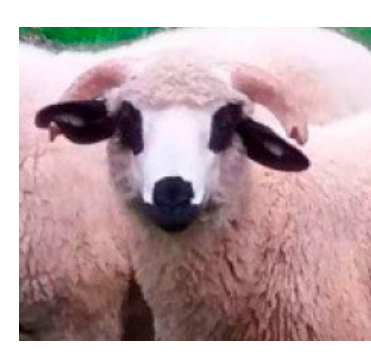

(b)

Figure 1. Protected designation of origin label of (a) Sjenica sheep cheese and (b) Sjenica sheep [38]. 
Sheep cheese production in Sjenica municipality is located on the most massive plateau in the Balkans and is one of the larger plains in Europe. The Sjenica-Pester plateau covers an area of $63 \mathrm{~km}^{2}$ at an altitude of $1150 \mathrm{~m}$ [39], as depicted in Figure 2. Approximately 35,000 to 40,000 sheep have been bred in this geographical area [38], and in 2016, 14,977 hectoliters of sheep milk were produced [40]. According to the technological process, $4 \mathrm{~L}$ of milk are needed on average for the production of $1 \mathrm{~kg}$ of cheese [41]. Thus, calculations indicate that approximately $370 \mathrm{t}$ of sheep cheese were produced in 2016.

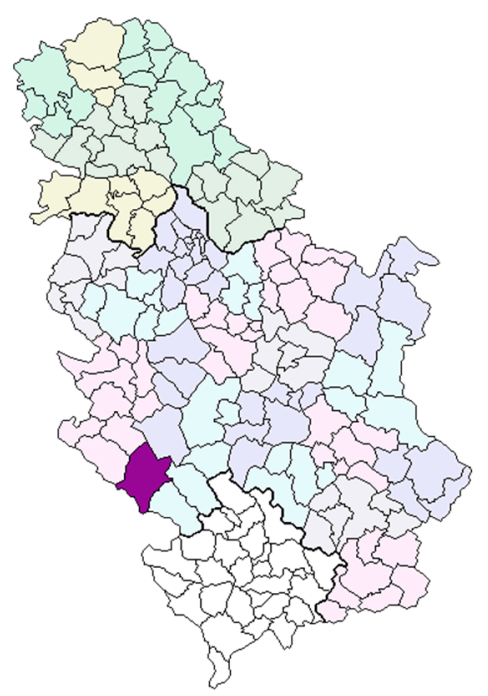

Figure 2. Production region of SSC presented in violet color in the map of Serbia [38].

The production of sheep cheese is characterized by the simplicity of its manufacturing process. Immediately after dairying, sheep milk is flowed through a gauze, and then rennet is added, which curdles milk into cheese. In the next stage, milk is blended and left for coagulation to occur. After a sufficiently solid mass forms, it is placed in a specific linen for cheese squeezing. The process of squeezing is based on gravity, without any additional treatment. The method of cheese formation lasts until there is no remaining curd in the cheese bundle. This part of the process is vital given as the quality of the cheese depends on this stage. In addition, it is essential that the temperature of the room where the boiling and pressing are carried out is not below $20^{\circ} \mathrm{C}$. After the squeezing, the cheese is cross-cut into slices and salted with a kitchen salt, and then placed in $20-70 \mathrm{~kg}$ vats. The furled cheese is loaded with 5 to $10 \mathrm{~kg}$ stones. The typical dairy plant and production vats are presented in the Figure 3 [38]. The period of maturation, since cheese is formed from raw milk, must be at least 60 days [39]. This relatively simple tradition of production has been maintained to this day.
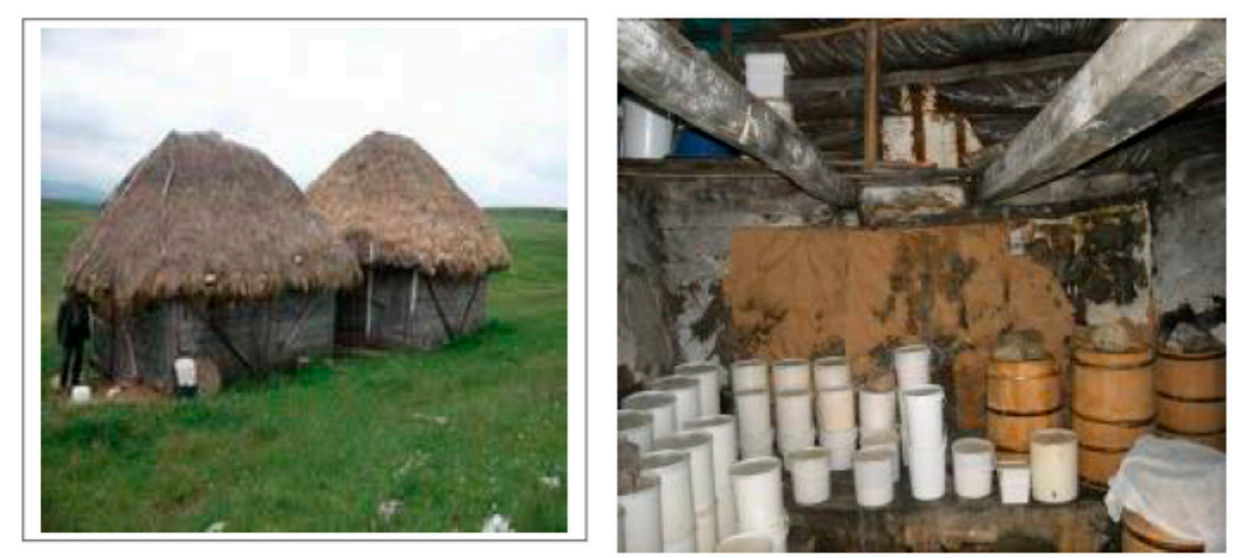

Figure 3. Dairy cottages of Sjenica-Pester plateau [37]. 
According to the last agricultural census [42], there are 5500 registered households and approximately $70 \%$ of them are oriented toward sheep farming in the territory of Sjenica. The majority of sheep farms are small (40-50 sheep), requiring only one full-time employee to handle all needed activities. Around $60 \%$ of the labor force is primary educated, whereas $36 \%$ have a secondary degree.

\subsection{SSC Supply Chain}

All stages of production (starting from the breeding of the sheep herds) of SSC are performed in the specific territory of the Sjenica-Pester plateau, in line with requirements for PDO registration [43]. In Figure 4, SSC supply chains are depicted according to the production subject-farm vs. dairy. Sheep breeders and milk producers are integrated and represent one actor in the SSC supply chain in both cases. At this level, the farm's production also incorporates the production of cheese. After the cheese production, farms usually sell their cheese to intermediaries (informal agents). Dairies most often purchase milk from the farms and sell the cheese either through their own shops or to wholesalers, which further distribute cheese to the retailers.

FARM

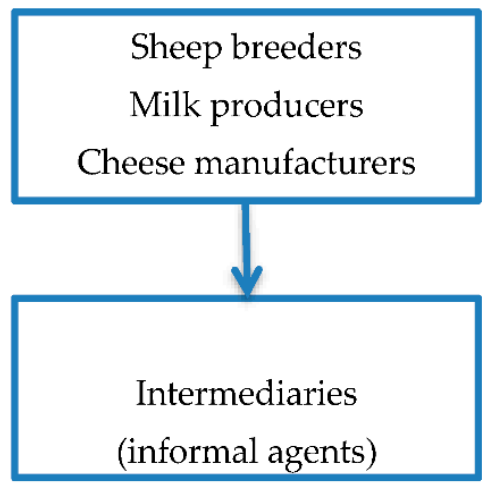

DAIRY

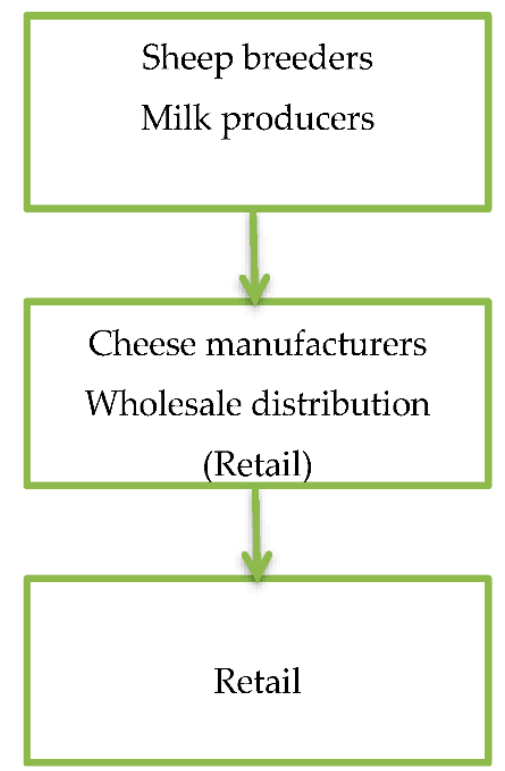

Figure 4. SSC supply chain for farms and dairies.

The association of the producers of Sjenica cheese was established in 2011 and included 15 actors [39]. However, over time, this association became less active in its work operations, whereas some bigger producers broke through and became leaders. There are five registered dairies that produce Sjenica cheese: Beni-komerc (annual production: $150 \mathrm{t}$ ), Turković (100 t), Magnat (80 t), FASS $(50 \mathrm{t})$, and Zenko-mlek $(20 \mathrm{t})$. There are four additional registered workshops for milk processing and production of cheese: Šanac (15 t), Sjenički delikatesi (5 t), Radoslav Vranić farm (5 t), and Jakup Selmanović farm (5 t) [44]. Thus, the biggest producers, both in terms of annual volume and revenues [45], are Beni komerc and Turković.

The other production facility of milk products (as well as of meat products) can be found in the Pešter Agro Cluster. This cluster was founded in 2013, aiming to develop agricultural production in the region of Sjenica, Tutin, and Novi Pazar. The activities of the cluster are supported by funds of the European Union and Switzerland, and their capacities amounted to $100 \mathrm{t}$ daily [46], but with constant increase in volume and products diversification [47].

The cheese producers and cheese distributors are usually integrated and constitute one level in the value chain, in terms of dairies. Therefore, Beni komerc, Turković, and the Pešter Agro Cluster 
consolidate all three cited business functions, where Profiko is the only SSC distributor that is not also a producer.

\subsection{The Market for SSC}

Even though the production volume exceeds the domestic consumption, the exported quantities of SSC are negligible [48]. This is mostly due to the restrictions imposed on its export to foreign markets, primarily by the EU [44]. Due to the method of cheese production, which does not include thermal processing, it cannot be exported to the EU market. Starting from 2018, the directives for the import of food to the EU from external countries have become even stricter, especially the rules regulating the import of traditional food [49]. Even though the European market is characterized by a high intake of dairy products per capita, including the considerable consumption of cheese, this market has entered the maturity phase of its life-cycle, as four out of the five the biggest dairy markets in Western Europe (Italy, France, Spain, and Great Britain) recorded a decrease in dairy sales in 2017 [50].

The decline was mainly induced by changes in consumer diets, which negatively impact the demand, whereas the other reason may be the market saturation with established cheese brands [50] and the preference of new generations to constantly strive for greater product diversity [51]. DOLs are usually perceived by consumers as signaling factors for higher quality and specific taste [52]. Consequently, consumers are willing to pay premium prices for cheese with DOL [32,52,53], which cannot be found in typical industrially produced cheese. Provided that production locations are usually found in remote rural areas and the usage of mechanization in the production process is minimal, the ecological aspect and healthy lifestyle associations, highly valued by consumers as sustainability facets $[54,55]$, became a common part of the communications of autochthonous cheeses.

Some differences from their European counterparts can be found in the regional market of the Western Balkans. According to Giraud et al. [56], the majority of regional consumers prefer expensive and industrially produced and packaged cheeses, which are sold in retail chains. They established that the smallest cluster of all included consumers favored locally produced cheeses. The authors [56] concluded that Serbian consumers vary less in their willingness to pay for cheese, but more in their sensory and point of purchase preferences. Considering listed global and regional trends, SSC producers should primarily consider the potential for their export to the international markets [44].

\section{Methods}

This study adopted a qualitative approach. The reason for conducting qualitative research was well summarized by Sayer [57], who explained that although quantitative data uses numbers, qualitative data uses meanings, where the meanings are expressed through language and action that create perceptions. Sounders et al. [58] stated that the goal of the researcher is to understand the fundamental meanings attached to organizational life, whereas other authors [59] clarified that social, political, cultural, economic, and ethnic factors differentiate the consensus and the different constructions.

Stepwise research design has been widely used in the investigation of social sciences [60-62], as well as in addressing marketing and organizational $[63,64]$ aspects. Following the protocol developed in previous studies that addressed the subject topic $[17,63,64]$, five stages of research were identified:

(1) Collection of relevant data from the literature and professional databases already available;

(2) Conducting interviews with all stakeholders along supply chain;

(3) Observations at the points of sales;

(4) Analysis of the promotional materials on SSC; and

(5) Deduction from theoretical frameworks and interpretation of the results.

Stepwise design involves diverse techniques for the analysis of varying practices distributed across collaborating actors. Observations and interviews were combined to obtain abundant data for the analysis of the effectiveness of SSC from the perspective of market-oriented sustainability. The main 
qualitative research technique used in the examination was performed through semi-structured interviews with the participants as a part of a mixed-method approach, as proposed in previous academic literature [65]. The advantage of semi-structured interviews is that they contain themes and questions that the researcher must cover, although they may vary from interview to interview. The researcher is able to omit some questions in particular, given a specific organizational context in relation to the research topic. It is possible that additional questions may be required to explore the research question and objectives, given the nature of events within a particular organization. Such interviews are typically conducted by audio-recording the conversation or note-taking [58].

This benefit of semi-structured interviews allows the researcher to use both methods of interview. The interviewer would have a set of pre-planned core questions for guidance, so that the same topics are covered with each interviewee. As the interview develops, the interviewee has the chance to explain or offer more relevant information according to the questions if they choose to do so [66]. If an interviewee experiences any difficulty in answering the questions, the interviewer is able to use cues or prompts to reassure the interviewee to dwell on the question more [67]. As David and Sutton [68] mentioned, having already identified key themes and questions provides the interviewer a sense of order from which to draw questions from unplanned information presented by the interviewee.

In the first stage of the research process, the author gathered relevant information from the resources already at our disposal, which served as the starting point for the development of the guidelines for the in-depth semi-structured interviews.

In the second stage, in-depth interviews were adapted to the specific information needs gathered from each stakeholder in the value chain. All levels of the value chain-milk producers and processors, distributors (direct and indirect), and consumers-were considered. Overall, 14 in-depth interviews were conducted: Five with the major producers of SSC (dairies and workshops), two with small producers (farmers), one with the representative of the producers' cluster, and six with diverse distributors (retailers, sellers on the farmers' market, and an agent). All SSC-producing dairies and manufacturing workshops were invited to take part in the research, and only two dairies and two workshops refused to participate. The study was complemented with 26 telephone interviews with the consumers. The detailed description of the research units, techniques applied for each of them, and examples of typical questions are provided in Appendix A (Table A1).

Through interviewing and observation, the author gained insights into the state of the SSC market and various challenges that various stakeholders encounter in their everyday work in this specific industry and food category. Specifically, milk producers and processors were asked about their management and employee structure, production indicators and process, and value chain relationships. The interview conducted with the representative of Pešter Agro Cluster pertained to their efforts to produce, distribute, and promote SSC in the regional market. Finally, consumers responded whether they were aware of SSC; and if they had tasted it, what was their opinion on the taste of SSC. They rated the taste on the five point Likert scale, ranging from "1-I do not like SSC taste at all" to "5-I like the taste of SSC very much". As many interviews were conducted by telephone, audio or video recording was not possible, therefore, researchers took notes to document these conversations. The analysis was complemented by observations of online shops. The final stage included processing, organizing, and systematizing the information.

Distributors were consulted on the availability of SSC on their points of sale, which was cross-checked by observations in the subject outlets. The representative of Profiko, the only distributor that is not also the producer, was surveyed on their strategy and motivation to perform distribution of this food product. In addition, one informal trade agent participated in the study, providing insights on the usual processes and networks that small farming households use to put their SSC product on the market. Four vendors at farmers' markets in the capital of Serbia responded to the questions regarding consumer awareness of SSC, their knowledge of the PDO label of this product, and their opinions and practices regarding the operation of the value chain. 
To address the final member of the supply chain—consumers [69]—-telephone interviewing was conducted with 26 participants. Given the limitations of this research technique, they were asked only two questions-if they have previously heard of SSC; and if they tasted it, to rate its flavor on the scale from 1 to 5 . The recruitment of the participants was completed using snowball sampling.

The next step in the research involved observation at the points of sale, where the SSC commercial availability, packaging, and sizes were recorded available in:

(1) 30 shops of the five biggest retailers: Idea, Roda, Maxi, Tempo, and Dis in Belgrade;

(2) 1 shop in Novi Pazar-the biggest city in the Sjenica region;

(3) 7 farmer's markets: 6 in Belgrade-Bajlonova, Mirijevska, Cvetkova, Novobeogradska, Zemunska, Kalenić, and 1 in the Northern Serbian city of Zrenjanin-Bagljaš; and

(4) the online selling points: Web shops, Facebook advertisements, and online market.

Each traditional point of sale was visited twice, while online selling points were visited three times in the period of one month. Attention was paid that one visit was performed during the working day and the other one during the weekend, which is particularly important for the farmer's market (due to their greater offer during the weekends).

The fourth stage involved the analysis of promotional materials, including inspection of packaging and advertisements on YouTube, given that, to the best of the author's knowledge, there were no other tools available for the promotion for SSC.

Finally, in the fifth stage, for the purpose of triangulation, the author linked data and drew conclusions from theoretical framework. The concluding phase was related to explanation and interpretation building.

\section{Results}

The findings of the research suggest that the prescribed method of milk processing and the preparation of cheese are applied throughout the production process by all interviewed enterprises. Following the set guidelines enables business actors in the SSC supply chain to label their cheese with the PDO certificate and promote it as such in the market [38]. All investigated companies involved in the production are characterized by being family-owned micro-enterprises, i.e., small businesses employing 10 people or fewer (family-style management and traditional organization, production depends on the amount of milk collected, control is unsupported by information systems, orders are sent from points of sale via telephone, and most product goes to stock [17]). In terms of marketing practices, Siu and Kirby [64] suggested that small firms usually do not have formal marketing policies and that they are unaware of their strategic decisions; therefore, they proposed analyzing stories about owner-managers and their companies to identify strategic marketing decisions in their firms. They implied that small firms are commonly less willing and able to co-operate with research, so they would be reluctant to answer direct questions related to some internal issues. Table 1 provides an overview of the most important characteristics of the enterprises that produce SSC.

Table 1 shows that most of the workers have a secondary school degree. Only in two cases had managers obtained a university degree-one from a Faculty of Agriculture and the other from a Faculty of Technology - both in the field of the engineering sciences. Even though all firms started as family enterprises, Beni-komerc and Turković expanded over time, as their annual revenues exceed $€ 1$ million [45] and their production volumes of cheese surpassed $100 \mathrm{t}$ [44]. All listed producers except Turković ground their business on dairy products-Sjenica cheese, kashkaval balkan, kajmak, and paprika in sour cream. Turković, as they are also a slaughterhouse, manufacture a wider array of products, including Sjenica lamb meat (PDO), veal and beef meat, and Sjenica prosciutto. The number of women in the production is slightly higher than the number of men, but all managers are men. 
Table 1. Characteristics of Sjenica sheep cheese production companies.

\begin{tabular}{|c|c|c|c|c|c|c|}
\hline Producer & $\begin{array}{c}\text { Type of } \\
\text { Organization }\end{array}$ & $\begin{array}{c}\text { Yearly } \\
\text { Production } \\
\text { Volume of } \\
\text { Sjenica } \\
\text { Cheese (in t) }\end{array}$ & $\begin{array}{c}\text { No. of } \\
\text { Workers } \\
\text { Involved in } \\
\text { Production }\end{array}$ & $\begin{array}{c}\text { Level of } \\
\text { Education }\end{array}$ & $\begin{array}{l}\text { No. of } \\
\text { Women vs. } \\
\text { No. of } \\
\text { Men } \\
\text { (W-M) }\end{array}$ & $\begin{array}{l}\text { Distribution } \\
\text { Channels }\end{array}$ \\
\hline Beni-komerc & $\begin{array}{l}\text { Small } \\
\text { enterprise-family } \\
\text { owned } \\
\text { (SE-FO) }\end{array}$ & 150 & $\begin{array}{c}8-10 \\
\text { workers } \\
1 \text { manager }\end{array}$ & $\begin{array}{c}\text { Workers: } \\
\text { elementary school } \\
\text { or secondary } \\
\text { school (SS) } \\
\text { Manager-SS }\end{array}$ & $5-5$ & $\begin{array}{c}\text { Supply retailers } \\
\text { mostly }\end{array}$ \\
\hline Turković & $\mathrm{SE}-\mathrm{FO}$ & 100 & $\begin{array}{l}10 \text { workers } \\
1 \text { manager }\end{array}$ & $\begin{array}{c}\text { Workers-SS } \\
\text { Manager-Faculty } \\
\text { education }\end{array}$ & $7-4$ & $\begin{array}{l}\text { Direct sale and } \\
\text { supply retailers }\end{array}$ \\
\hline FASS & $\mathrm{SE}-\mathrm{FO}$ & 50 & $\begin{array}{l}5 \text { workers } \\
1 \text { manager }\end{array}$ & $\begin{array}{c}\text { Workers-SS } \\
\text { Manager-College } \\
\text { degree }\end{array}$ & $4-2$ & $\begin{array}{c}\text { Supply retailers } \\
\text { mostly }\end{array}$ \\
\hline $\begin{array}{l}\text { Sjenički } \\
\text { delikatesi }\end{array}$ & $\mathrm{SE}-\mathrm{FO}$ & 5 & 3 workers & SS & $1-2$ & $\begin{array}{l}\text { No distribution } \\
\text { (partnership } \\
\text { with other } \\
\text { producers) }\end{array}$ \\
\hline $\begin{array}{c}\text { Jakup } \\
\text { Selmanović }\end{array}$ & FO farm & 5 & 4 workers & $\begin{array}{c}\text { 3-SS } \\
\text { 1-Faculty } \\
\text { education }\end{array}$ & $2-2$ & $\begin{array}{l}\text { Supply of local } \\
\text { retailers }\end{array}$ \\
\hline
\end{tabular}

Interviews with two farmers, who are at the same time sheep breeders, milk producers, and micro-producers of SSC, revealed the many challenges they face. Each farm has a herd of approximately 40 sheep, so their production volume is rather small, but in line with the regional average farm size [42]. They emphasized the complete lack of collaboration either with local bigger producers (dairies) or with structures of agriculturists or processors. They feel suspicious about the possibilities of establishing and participating in this potential cooperative network, considering it to be useless. This finding is in accordance with the situation revealed in other post-socialist countries in Central and Eastern Europe [70-72]. Due to extremely underdeveloped infrastructure [38,41], inconsistent quality of the cheese produced by various producers [46], and intensive distrust in cooperatives [73] in the region in general, participants in this survey do not perceive any benefits that might arise from joining into associations.

The interviewees highlighted their difficulties in putting their products on the market, which is usually performed by informal trade agents who buy cheese directly on the farm from several farmers in the village and sell it further through their distribution channel, usually at farmers' markets in bigger cities in Serbia (as reported by the interviewed trade agent). Respondents also mentioned that this method of distribution is only one that they perceive to be feasible, given that agents also perform transportation. They do not have adequate transportation means as the road infrastructure in this region is poor and winter often lasts for seven months in this territory. Finally, respondents commented that aging of the family members who work on the farms and their primary education level, supported also by the findings of the agricultural census in Serbia [42], severely hinder the improvement of the business.

Following the flow of the supply chain, the next subject of the investigation were the intermediaries. All investigated companies, beside one, were wholesalers (and in the case of Turković, they were also retailers), supplying retailers in Belgrade and in Vojvodina (the northern region of Serbia), as well as in the Sjenica municipality. The smallest one, Sjenički delikatesi, distributed its products to Sjenica and the nearby towns of Novi Pazar and Tutin.

Previous data suggest that Turković and Beni-komerc produce almost half of all sectoral SSC [44], which is also reflected in their distribution strategy and market share. Turković owns eight shops (two in Sjenica, four in Belgrade, and one each in Novi Sad and Prijepolje), and they also supply 
some retailers that are not members of the biggest national retailing chains. Beni-komerc does not possess their own points of sales, but they supply the biggest retailing chains with SSC - Maxi, Roda, and Tempo. Observation fieldwork showed that SSC is not available in the other two nationally present retailing chains-Dis and Idea. The same challenges appear to be shared by less recognizable PDO cheeses in Europe [17], but also some well-known DOLs [18]. The prices at both distribution levels—wholesalers and retailers—are depicted in Table 2.

Table 2. SSC prices according to point of sale.

\begin{tabular}{cccc}
\hline \multicolumn{2}{c}{ Wholesalers } & \multicolumn{2}{c}{ Retailers } \\
\hline Name & Price $(\boldsymbol{\epsilon} / \mathbf{k g})$ & Name & Price $(\boldsymbol{\epsilon} / \mathbf{k g})$ \\
\hline Turković & 3.00 & Turković shops & 3.56 \\
Beni-komerc & 3.80 & Retailing chains & 5.68 \\
Profiko & 3.90 & Pešter agro cluster & 5.93 \\
Farms-small producers & $2.50-3.00$ & Farmers' market & 5.00 \\
& & Online POS & $3.40-5.00$ \\
\hline
\end{tabular}

In investigated retail stores and farmers' markets, SSC is sold without industrial packaging, as a bulk cheese. This is not surprising, as in the production process, cheese is packed in vats of $20-70 \mathrm{~kg}$. Manufacturers are not interested in the possibility of packing cheese in smaller packages (whether wood or plastic), since they argue that different packaging would reduce cheese quality. However, large packaging significantly complicates transportation and limits selling options, as reported by the retailers in this study. Certain retailers (e.g., Maxi and Profiko) repack cheese to smaller 1-5 kg packages (either plastic vacuum bag or canister), which increases the product's price, but facilitates manipulation in the shop and for consumers. Previous studies revealed that packaging is an important product feature from the perspective of consumers [22,74], and in Serbia, consumers highly consider packaging in their shopping choice [56]. Inconvenient packaging is the main disadvantage cited by four sellers in the farmers' market included in this study.

These sellers are not at all aware of the existence of the PDO label for SSC and report that their customers do not ask for this indication either. They always purchase cheese from trade agents and in average pay $€ 3.70 / \mathrm{kg}$. Vendors noted that they sell very small quantities of cheese, along with the greater range of dairy products that they offer. Their customers reported the unstandardized level of quality from time to time and doubts related to the sanitary conditions and origin of the cheese, echoing findings of other academic studies [41,47]. However, in all major farmers' markets in Belgrade (the seven listed in the previous section of this paper), Sjenica cheese can be found throughout the year.

Profiko is the only distributor of SSC that is not also a producer. However, according to their top manager, they plan to start up manufacturing too: "Our ambition for the future period is to open as many quality retail stores as possible and establish our own production of cheese, kajmak, and kashkaval balkan."

The company has operated since 1996 and as of 2018 possessed 20 retail stores in Northern Serbia (retail chain named Mlečno carstvo) and supply with dairy products some of big retail chains: Rodić, Mercator, Dis, Univerexport, etc. They also supply restaurants, hotels, coffee shops, bakeries, and public institutions with dairy products. They have vast storage space and eight vehicles, all equipped with modern technology. There are 80 employees in the company, mostly with secondary education degrees, whereas managers mostly possess university degrees (information on the types of degrees were not disclosed to researcher). Cheeses with PDOs constitute a significant part of their commercial offer and encompass various and numerous types: Sjenica, Zlatar, Homolje, Pirot, Zlatibor, Pljevlja, etc.

The fourth distribution channel, which is becoming increasingly relevant [50], is the online point of sale. The analysis focused on the pervasive virtual spaces, i.e., Facebook pages, auction sites, and web shops. The findings of this research indicate that there are various ads for Sjenica cheese across the web space, including specialized pages on Facebook for selling Sjenica cheese. There are dedicated 
websites for the same purpose and advertisements on an auction website, lalafo.rs. None of the online points of sale provide any information on the PDO label, nor details on the product content-if it is produced from cow or sheep milk. The packaging is offered in two sizes, 5 and $10 \mathrm{~kg}$, with prices ranging from $€ 3.40$ to $5.00 / \mathrm{kg}$.

The final member of the supply chain is the consumer. As previously explained, due to the limitations imposed by the telephone interviewing technique, 26 respondents were asked if they recognize SSC and to assess its taste if they had previously experienced it. Their answers are presented in Table 3.

Table 3. Consumer recognition and estimation of SSC.

\begin{tabular}{cccc}
\hline Region in Serbia & No. Respondents & $\begin{array}{c}\text { Recognize Sjenica } \\
\text { Sheep Cheese }(\boldsymbol{n})\end{array}$ & Grade (1-5) * \\
\hline West & 8 & 6 & 4 \\
East & 3 & 2 & 3 \\
North & 6 & 4 & 3 \\
South & 9 & 8 & 5 \\
Total & 26 & 20 & \\
\hline
\end{tabular}

To ensure a holistic approach and comprehensive analysis of the SSC market sustainability, from the perspective of signaling theory [21,22], the promotional tools were investigated. Sjenica cheese is only mentioned in a promotional video spot created by the National Tourism Organization of Serbia representing autochthonous food and beverages for the Soulfood Serbia campaign. To the best of the author's knowledge, there are no other promotional activities regarding this product in the media (neither advertisements nor public relation posts) or through sales promotion tools.

\section{Discussion}

Sustainability has become a key concept for both organizations and marketing researchers. Increasing the efficiency of the supply chain can contribute to the economic sustainability of the local community in which stakeholders operate, supports the development of rural areas by enabling product differentiation potential for manufacturers [5,6], expands the selection for consumers [3], and reinforces the growth of tourism in the local area [7].

The main body of results analyzed in this study imply that the SSC supply chain performance can be improved significantly at each level. Grounded on the notions of RDT, the author concluded that all analyzed business members strive to and engage their efforts in the increase in their bargaining power, even if these actions produce modest outcomes. These dissatisfying results, as proposed by UET applied to previous studies [28,29], in this case can be due to the inadequate educational level and ages of the top management of the supply chain actors. The other reason for the low efficacy of the SSC supply chain may be that, as posited by signaling theory, the majority of the investigated members in the supply chain possess very low awareness of the DOL awarded to SSC, and thus do not associate this observable proxy with underlying product perception constructs, such as: Artisan cheese, healthy food, and cultural legacy, as is the usual case for products with PDOs [20,21,31,32].

The findings implied that the structure of milk and cheese producers in this case is atomized as in sheep farming, which leads to their limited bargaining power. RDT argues that, in this situation, organizations generally respond to resource dependencies (i.e., the lack of distribution channels in this case) by forming inter-organizational arrangements, like associations [25]. Therefore, in this study, the reluctance of small producers-farmers—-to enter into the existing association (e.g., Pešter agro cluster) might appear surprising. We should be reminded that RDT also postulates that business agents implement sustainability initiatives if they would enable them to obtain additional freedom from dependence on others for resources [23], whereas farmers in this study expressed doubts in this outcome. The farmers' attitudes should be understood from a contextual level too, given 
that post-socialist countries, including Serbia, share distrust in collective structures [70-73]. Hence, initiatives on the education of farmers would be beneficial to inform them of the advantages of access to associations or clusters, as well as of the standardization of the process of production of SSC. Currently, in line with this study's findings, small producers can be only price-takers, offering their products significantly cheaper than dairies. The Pešter agro cluster might become a more important market player with a larger market share, but only if it overcomes the stipulated barriers.

The low bargaining power of the investigated small producers is understandable due to the listed reasons. However, the lack of a more substantial power of the big dairies, which produce more than half of the total annual production volume of the sector [40,42], is rather intriguing. The author thinks that the explanation should be examined using UET. The analysis showed that big dairies (Turković, Beni-komerc, and FOSS), as well as the big dairy products distributor (Profiko), were established and are operated as family companies. Consequently, strategic decisions are made by family members and not by professional managers. UET asserts that executive's characteristics, predominantly age and formal education [28], significantly determine an organization's performance. In addition, UET posits that not only is the manager's possession of a university degree positively correlated with firm's effectiveness, but also it is important that the degree is business-related [28]. Turković offers SSC at a lower price than their competitors, whereas Beni-komerc produces SSC under the private label of a big retailer chain and, hence, sells at the wholesaler, but not retailer, price. As such, the author concludes that the lack of management competencies in both firms impedes their further growth. These restraints also can negatively affect recognition of the PDO label of SSC in the market, provided that the producers should be the main advocates and promoters of this label.

Producers are not only members of the supply chain that should be in charge of the promotion and popularization of SSC, aimed at the achievement of better market results. Intermediaries may also receive significant economic and image benefits of the promotion of their sustainability initiatives, as proposed by signaling theory [30]. However, signaling theory cites that companies use costly cues to signal their commitment to sustainability only if consumers and other partners vigilantly scan the environment for signals and if these mechanisms are highly observable. The observation made by vendors in the farmers' markets and evidence from this survey suggest that the downstream levels of the supply chain do not yet recognize the importance of PDOs as indicators of sustainability. This conclusion is corroborated by findings of previous studies [56] in the subject market. Thus, the utility of the certification process and justification of its cost if the market does not recognize this signal should be questioned. However, recent campaigns for the promotion of Pirot cheese (very similar cheese to SSC, produced in the same region and having a PDO label) and of local products (fruits and vegetables) in the biggest retailing chains in Serbia imply that PDO can be a significantly positive signal for consumers if the meaning of the PDO label is explained to them. An additional challenge in this particular case rests in the fact that the association of the producers of Sjenica cheese, which is the legal owner of the SSC PDO label [38], has become inactive over the course of time. Hence, producers may have doubts about who to address if they want to obtain this label. The complete lack of communication activities related to the SSC requires improvement of the PDO label comprehension by all members in the SSC supply chain and their better coordination.

\section{Conclusions}

The findings suggest that producing and marketing SSC with PDO might be a promising strategy for quality differentiation and enhanced business results, particularly in the southwestern parts of the country where SSC is produced. Retailers and producers will likely profit from developing information campaigns with a focus on the sustainability aspects of PDOs to increase consumers' knowledge of its meaning and significance for the community, thus creating preferences and influencing purchase behavior. Policy makers and producers' associations should invest more in the education of the producers of SSC related to the standardization of the manufacturing process, as well as into monitoring and control of the quality and authenticity of SSC offered in the market. Building trust among 
various stakeholders and the development of collaboration networks along the SSC supply chain will presumably help their business results by joint marketing presentation, both in domestic and international markets. Regarding the limited education levels of manufacturers and especially their management, which restrain further expansion of their companies, knowledge transfer from foreign associations owning PDOs and experts in business administration and the production process may be quite useful.

Gaining a deeper understanding of consumers' attitudes and their buying motives regarding different sustainability attributes related to DOLs is recommended for future studies. Given that this study did not identify articles examining purchase behavior in real market scenarios with real market transactions in this region, future research should focus on bridging that gap. The contribution of SSC to the tourism and economy of the local region should be explored to exercise these potentials in the future and improve the sustainability of the local community.

There are several limitations of this study. Firstly, the research applied a qualitative method and a stepwise research design, which restrained us from drawing more general conclusions. Accuracy in interviewees' presentation, extent of knowledge on the investigated company's features, and consistency in the emphasis of certain aspects of the company are major drawbacks to using in-depth interviews. The author attempted to overcome this challenge through triangulation of the data by using several investigation methods (interviewing, review of secondary data, and observations). Thirdly, the rather small number of consumers in the exploratory study enabled us to acquire only preliminary insights into consumers' attitudes and knowledge of SSC PDO and to try to distinguish potential topics for further research. Additional investigations with larger samples are needed to better understand this topic. Furthermore, observation was predominantly performed in the capital city and in two retail formats, whereas the research may benefit from a nation-wide inspection into various selling formats. Finally, the lack of similar investigations in the Serbian market and the lack of distinguishing between PDO and PGI in the Serbian legislation restrict comparison of the findings of this study to those conducted in the subject field.

In the future, ongoing debate about showcasing national cultural heritage from the point of view of tourism development, food scarcity, and related trends appears likely to increase the importance of sustainability to firms and the scholars that study them. The conclusions derived and methodology applied in this study are thought to serve as efficient guidelines for future research related to market-oriented sustainability. The findings of this research indicated that there is room both in marketing science and the industrial sector of SSC for this kind of innovation and reasoning.

Funding: This research was funded by European Commission, Horizon 2020 Project Strength2Food, grant number 678024 .

Acknowledgments: This paper is based on research undertaken as part of Horizon 2020 Project Strength2Food (No. 678024).

Conflicts of Interest: The author declares no conflict of interest. The funders had no role in the design of the study; in the collection, analyses, or interpretation of data; in the writing of the manuscript, or in the decision to publish the results.

\section{Appendix A}

Table A1. Description of research units.

\begin{tabular}{ccccc}
\hline No. & Respondent Type & Name & Research Tool & Examples of Questions \\
\hline 1 & Producer: dairy & Beni komerc & $\begin{array}{c}\text { Semi-structured } \\
\text { interview }\end{array}$ & $\begin{array}{l}\text { Structure of staff (sex, education, positions), relations with } \\
\text { other stakeholders along supply chain, yearly production, } \\
\text { recognition and use of PDO label for SSC, etc. }\end{array}$ \\
\hline 2 & Producer: dairy & Turković & $\begin{array}{c}\text { Semi-structured } \\
\text { interview }\end{array}$ & Same as previous \\
\hline 3 & Producer: dairy & FASS & $\begin{array}{c}\text { Semi-structured } \\
\text { interview }\end{array}$ & Same as previous \\
\hline
\end{tabular}


Table A1. Cont.

\begin{tabular}{|c|c|c|c|c|}
\hline No. & Respondent Type & Name & Research Tool & Examples of Questions \\
\hline 4 & Producer: dairy & Sjenički delikatesi & $\begin{array}{l}\text { Semi-structured } \\
\text { interview }\end{array}$ & Same as previous \\
\hline 5 & Producer: dairy & $\begin{array}{l}\text { Jakup Selmanović } \\
\text { farm }\end{array}$ & $\begin{array}{l}\text { Semi-structured } \\
\text { interview }\end{array}$ & Same as previous \\
\hline 6 & Producer: farm & Family 1 & $\begin{array}{l}\text { Semi-structured } \\
\text { interview }\end{array}$ & $\begin{array}{l}\text { Organization of the production and distribution, obstacles } \\
\text { that they meet in marketing of SSC, understanding of values } \\
\text { of PDO label, willingness to join cooperatives (or clusters), etc. }\end{array}$ \\
\hline 7 & Producer: farm & Family 2 & $\begin{array}{l}\text { Semi-structured } \\
\text { interview }\end{array}$ & Same as previous \\
\hline 8 & Producers' cluster & Pešter Agro Cluster & $\begin{array}{l}\text { Semi-structured } \\
\text { interview }\end{array}$ & $\begin{array}{l}\text { Organization of the production and distribution, obstacles } \\
\text { that they meet in marketing of SSC and acquisition of new } \\
\text { members, understanding of values of PDO label, relations } \\
\text { with other stakeholders along supply chain, yearly } \\
\text { production, etc. }\end{array}$ \\
\hline 9 & Retailer & Profiko & $\begin{array}{l}\text { Semi-structured } \\
\text { interview }\end{array}$ & $\begin{array}{l}\text { Understanding of values of PDO label, their plans for } \\
\text { assortment of their portfolio in the future, quality of relations } \\
\text { with producers, etc. }\end{array}$ \\
\hline 10 & $\begin{array}{l}\text { Seller at farmers' } \\
\text { market }\end{array}$ & $\begin{array}{l}\text { Individual } \\
\text { Bajlonova }\end{array}$ & $\begin{array}{l}\text { Semi-structured } \\
\text { interview }\end{array}$ & $\begin{array}{l}\text { How they procure SSC, motives to keep SSC in their } \\
\text { assortment, consumers' comments on the quality of SSC and } \\
\text { DOLs, etc. }\end{array}$ \\
\hline 11 & $\begin{array}{l}\text { Seller at farmers' } \\
\text { market }\end{array}$ & $\begin{array}{l}\text { Individual } \\
\text { Cvetkova }\end{array}$ & $\begin{array}{l}\text { Semi-structured } \\
\text { interview }\end{array}$ & Same as previous \\
\hline 12 & $\begin{array}{l}\text { Seller at farmers' } \\
\text { market }\end{array}$ & Individual Kalenić & $\begin{array}{l}\text { Semi-structured } \\
\text { interview }\end{array}$ & Same as previous \\
\hline 13 & $\begin{array}{l}\text { Seller at farmers' } \\
\text { market }\end{array}$ & $\begin{array}{l}\text { Individual } \\
\text { Mirijevska }\end{array}$ & $\begin{array}{l}\text { Semi-structured } \\
\text { interview }\end{array}$ & Same as previous \\
\hline 14 & Trade agent & Individual 1 & $\begin{array}{l}\text { Semi-structured } \\
\text { interview }\end{array}$ & Same as previous \\
\hline $15-41$ & Consumers & Consumers & $\begin{array}{l}\text { Telephone } \\
\text { interview }\end{array}$ & $\begin{array}{l}\text { Have you previously heard of SSC? } \\
\text { If you have tasted it before, please rate its flavor on a scale } \\
\text { from } 1 \text { to } 5 \text {. }\end{array}$ \\
\hline 42 & Retail chain & Idea & Observation & $\begin{array}{l}\text { Availability, package size and design, price, weight, presence } \\
\text { of PDO label, etc. }\end{array}$ \\
\hline 43 & Retail chain & Roda & Observation & $\begin{array}{l}\text { Availability, package size and design, price, weight, presence } \\
\text { of PDO label, etc. }\end{array}$ \\
\hline 44 & Retail chain & Maxi & Observation & $\begin{array}{l}\text { Availability, package size and design, price, weight, presence } \\
\text { of PDO label, etc. }\end{array}$ \\
\hline 45 & Retail chain & Tempo & Observation & $\begin{array}{l}\text { Availability, package size and design, price, weight, presence } \\
\text { of PDO label, etc. }\end{array}$ \\
\hline 46 & Retail chain & Dis & Observation & $\begin{array}{l}\text { Availability, package size and design, price, weight, presence } \\
\text { of PDO label, etc. }\end{array}$ \\
\hline 47 & Retailer & Novi Pazar & Observation & $\begin{array}{l}\text { Availability, package size and design, price, weight, presence } \\
\text { of PDO label, etc. }\end{array}$ \\
\hline 48 & Farmers' market & Bajlonova & Observation & $\begin{array}{l}\text { Availability, package size and design, price, weight, presence } \\
\text { of PDO label, etc. }\end{array}$ \\
\hline 49 & Farmers' market & Mirijevska & Observation & $\begin{array}{l}\text { Availability, package size and design, price, weight, presence } \\
\text { of PDO label, etc. }\end{array}$ \\
\hline 50 & Farmers' market & Cvetkova & Observation & $\begin{array}{l}\text { Availability, package size and design, price, weight, presence } \\
\text { of PDO label, etc. }\end{array}$ \\
\hline 51 & Farmers' market & Novobeogradska & Observation & $\begin{array}{l}\text { Availability, package size and design, price, weight, presence } \\
\text { of PDO label, etc. }\end{array}$ \\
\hline 52 & Farmers' market & Zemunska & Observation & $\begin{array}{l}\text { Availability, package size and design, price, weight, presence } \\
\text { of PDO label, etc. }\end{array}$ \\
\hline 53 & Farmers' market & Kalenić & Observation & $\begin{array}{l}\text { Availability, package size and design, price, weight, presence } \\
\text { of PDO label, etc. }\end{array}$ \\
\hline 54 & Farmers' market & Bagljaš Zrenjanin & Observation & $\begin{array}{l}\text { Availability, package size and design, price, weight, presence } \\
\text { of PDO label, etc. }\end{array}$ \\
\hline 55 & Online point of sale & lalafon & Observation & $\begin{array}{l}\text { Availability, package size and design, price, weight, presence } \\
\text { of PDO label, etc. }\end{array}$ \\
\hline 56 & Online point of sale & Facebook & Observation & $\begin{array}{l}\text { Availability, package size and design, price, weight, presence } \\
\text { of PDO label, etc. }\end{array}$ \\
\hline 57 & Other & $\begin{array}{l}\text { YouTube, online, } \\
\text { etc. }\end{array}$ & Observation & Promotion \\
\hline
\end{tabular}




\section{References}

1. Chabowski, B.R.; Mena, J.A.; Gonzalez-Padron, T.L. The structure of sustainability research in marketing, 1958-2008: A basis for future research opportunities. J. Acad. Mark. Sci. 2011, 39, 55-70. [CrossRef]

2. Closs, D.J.; Speier, C.; Meacham, N. Sustainability to support end-to-end value chains: The role of supply chain management. J. Acad. Mark. Sci. 2011, 39, 101-116. [CrossRef]

3. Guerrero, L.; Guàrdia, M.D.; Xicola, J.; Verbeke, W.; Vanhonacker, F.; Zakowska-Biemans, S.; Sajdakowska, M.; Sulmont-Rossé, C.; Issanchou, S.; Contele, M.; et al. Consumer-driven definition of traditional food products and innovation in traditional foods. A qualitative cross-cultural study. Appetite 2009, 52, 345-354. [CrossRef] [PubMed]

4. Rodríguez-Entrena, M.; Salazar-Ordóñez, M.; Cordón-Pedregosa, R.; Cardenas, J.L. Analysing granulated brown sugar-panela-market in Western Honduras. Br. Food J. 2016, 118, 495-512. [CrossRef]

5. Avermaete, T.; Viaene, J.; Morgan, E.J.; Pitts, E.; Crawford, N.; Mahon, D. Determinants of product and process innovation in small food manufacturing firms. Trends Food Sci. Technol. 2004, 15, 474-483. [CrossRef]

6. Johns, T.; Powell, B.; Maundu, P.; Eyzaguirre, P.B. Agricultural biodiversity as a link between traditional food systems and contemporary development, social integrity and ecological health. J. Sci. Food Agric. 2013, 93, 3433-3442. [CrossRef] [PubMed]

7. Sims, R. Food, place and authenticity: Local food and the sustainable tourism experience. J. Sustain. Tour. 2009, 17, 321-336. [CrossRef]

8. Cerutti, A.K.; Bruun, S.; Donno, D.; Beccaro, G.L.; Bounous, G. Environmental sustainability of traditional foods: The case of ancient apple cultivars in Northern Italy assessed by multifunctional LCA. J. Clean. Prod. 2013, 52, 245-252. [CrossRef]

9. Krystallis, A.; Chrysochou, P.; Perrea, T.; Tzagarakis, N. A retrospective view on designation of origin labeled foods in Europe. J. Int. Food Agribus. Mark. 2017, 29, 217-233. [CrossRef]

10. Parrott, N.; Wilson, N.; Murdoch, J. Spatializing quality: Regional protection and the alternative geography of food. Eur. Urban Reg. Stud. 2002, 9, 241-261. [CrossRef]

11. Ismea Fondazione Qualivita. RAPPORTO 2017 ISMEA-QUALIVITA Sulle Produzioni Agroalimentari e Vitivinicole Italiane DOP, IGP e STG; Fondazione Qualivita: Rome, Italy, 2017; ISBN 9788896530467.

12. Velčovská, Š.; Sadílek, T. Certification of cheeses and cheese products origin by EU countries. Br. Food J. 2015, 117, 1843-1858. [CrossRef]

13. Connelly, B.L.; Ketchen, D.J.; Slater, S.F. Toward a "theoretical toolbox" for sustainability research in marketing. J. Acad. Mark. Sci. 2011, 39, 86-100. [CrossRef]

14. Varadarajan, R. Toward sustainability: Public policy, global social innovations for base-of-the-pyramid markets, and demarketing for a better world. J. Int. Mark. 2014, 22, 1-20. [CrossRef]

15. Economist Intelligence Unit: Sustainability across Borders. Available online: http://www.eiu.com/report_ dl.asp?mode=fi\&fi=123934397.PDF (accessed on 20 December 2018).

16. Haanaes, K.; Balagopal, B.; Arthur, D.; Kong, M.T.; Velken, I.; Kruschwitz, N.; Hopkins, M.S. First look: The second annual sustainability \& innovation survey. MIT Sloan Manag. Rev. 2011, 52, 76-84.

17. Coelho, D.A.; Carrola, T.E.; Couvinhas, A.F. Improvement of Certified Artisan Cheese Production through Systemic Analysis-Serra da Estrela PDO. Sustainability 2017, 9, 468. [CrossRef]

18. O'Reilly, S.; Haines, M.; Arfini, F. Small and medium sized food enterprise networks in supply chains: The case of Parma Ham. In Paradoxes in Food Chains and Networks, Proceedings of the Fifth International Conference on Chain and Network Management in Agribusiness and the Food Industry, Noordwijk, The Netherlands, 6-8 June 2002; Trienekens, J.H., Omta, S.W.F., Eds.; Wageningen Academic Publishers: Wageningen, The Netherlands, 2002; Volume 6, pp. 768-779. [CrossRef]

19. Krug, J.A. Executive turnover in acquired firms: An analysis of resource-based theory and the upper echelons perspective. J. Manag. Gov. 2003, 7, 117-143. [CrossRef]

20. Zhou, L.; Yang, Z.; Hui, M.K. Non-local or local brands? A multi-level investigation into confidence in brand origin identification and its strategic implications. J. Acad. Mark. Sci. 2010, 38, 202-218. [CrossRef]

21. Dopico, D.C.; Mendes, R.; Silva, H.A.; Verrez-Bagnis, V.; Pérez-Martín, R.; Sotelo, C.G. Evaluation, signalling and willingness to pay for traceability. A cross-national comparison. Span. J. Mark. ESIC 2016, 20, $93-103$. [CrossRef] 
22. Javeed, A.; Bin Mod Mokhtar, S.S.; Bin Lebai, I. Perceived Product Quality: Role of Extrinsic Cues. J. Manag. Sci. 2017, 11, 195-220.

23. Drees, J.M.; Heugens, P.P. Synthesizing and extending resource dependence theory: A meta-analysis. J. Manag. 2013, 39, 1666-1698. [CrossRef]

24. Wang, Y.; Qu, Z.; Tan, B. How Do Assurance Mechanisms Interact in Online Marketplaces? A Signaling Perspective. IEEE Trans. Eng. Manag. 2018, 65, 239-251. [CrossRef]

25. Orlitzky, M.; Schmidt, F.L.; Rynes, S.L. Corporate social and financial performance: A meta-analysis. Organ. Stud. 2003, 24, 403-441. [CrossRef]

26. Hambrick, D.C. Upper echelons theory: An update. Acad. Manag. Rev. 2007, 32, 334-343. [CrossRef]

27. Hambrick, D.C. Upper Echelons Theory. In The Palgrave Encyclopedia of Strategic Management; Augier, M., Teece, D., Eds.; Palgrave Macmillan: London, UK, 2016; pp. 1-5.

28. Wang, G.; Holmes, R.M., Jr.; Oh, I.S.; Zhu, W. Do CEOs matter to firm strategic actions and firm performance? A meta-analytic investigation based on upper echelons theory. Pers. Psychol. 2016, 69, 775-862. [CrossRef]

29. Hiebl, M.R. Upper echelons theory in management accounting and control research. J. Manag. Control 2014, 24, 223-240. [CrossRef]

30. McDonald, S.; Oates, C.J. Sustainability: Consumer perceptions and marketing strategies. Bus. Strategy Environ. 2006, 15, 157-170. [CrossRef]

31. Unnevehr, L.; Eales, J.; Jensen, H.; Lusk, J.; McCluskey, J.; Kinsey, J. Food and consumer economics. Am. J. Agric. Econ. 2010, 92, 506-521. [CrossRef]

32. Schäufele, I.; Hamm, U. Consumers' perceptions, preferences and willingness-to-pay for wine with sustainability characteristics: A review. J. Clean. Prod. 2017, 147, 379-394. [CrossRef]

33. Shrivastava, P. The role of corporations in achieving ecological sustainability. Acad. Manag. Rev. 1995, 20, 936-960. [CrossRef]

34. Aprile, M.C.; Caputo, V.; Nayga, R.M., Jr. Consumers' valuation of food quality labels: The case of the European geographic indication and organic farming labels. Int. J. Consum. Stud. 2012, 36, 158-165. [CrossRef]

35. Rangnekar, D. The Socio-Economics of Geographical Indications: A Review of Empirical Evidence from Europe; Issue Paper; UNCTAD-ICTSD Project on IPRs and Sustainable Development: Geneva, Switzerland, 2004; Volume 8.

36. The List of Protected Geographical Indications Registered in the Intelectual Property Office. Available online: http:/ / www.zis.gov.rs/prava-intelektualne-svojine/oznake-geografskog-porekla/spisak-ogp.953. html (accessed on 28 August 2018).

37. DOOR Agricultural and Rural Development. Available online: http:/ / ec.europa.eu/agriculture/quality / door/list.html (accessed on 28 August 2018).

38. Popović-Vranješ, A.; Graca, F.; Bauman, F. Elaborate for Protection of the Designation of Origin of Sjenica Sheep Ceheese; Udruženje Proizvođača Sjeničkog Sira "Sjenički Sir": Belgrade, Serbia, 2011.

39. Arandarenko, M.; Bojić, K.; Ognjanov, G.; Mitić, S.; Vojvodičan, M. Analysis of the Local Labour Market: Final Report; Foundation for the Advancement of Economics: Belgrade, Serbia, 2008.

40. Farm Accountancy Data Network-FADN. Available online: https://www.fadn.rs/ (accessed on 19 August 2018).

41. Jovanović, S.T.; Maćej, O.D.; Barać, M.B. Characteristics of autochthonous production of Sjenica cheese at Sjenica-Pester plateau region. Biotechnol. Anim. Husb. 2004, 20, 131-139. [CrossRef]

42. Agricultural Census. Available online: http://popispoljoprivrede.stat.rs/?page_id=6221 (accessed on 26 July 2018).

43. Quality Schemes Explained. Available online: https://ec.europa.eu/info/food-farming-fisheries/ food-safety-and-quality/certification/quality-labels/quality-schemes-explained_en (accessed on 20 November 2018).

44. Regional Center for Development of Agriculture and Village-Sjenica, Finding New Markets for Sjenica Cheese. Available online: http:/ / regionalnicentar.org.rs/naci-nova-trzista-za-sjenicki-sir/ (accessed on 23 October 2018).

45. Serbian Business Registers Agency. Available online: http://www.apr.gov.rs/eng/Home.aspx (accessed on 23 July 2018). 
46. BIZLife, Pester Agro Cluster is Established. Available online: https://www.bizlife.rs/uncategorized/54971konstituisan-pester-agro-klaster/ (accessed on 24 July 2018).

47. Agrosrbija, Kajmak for the International Market Too. Available online: http://agrosrbija.com/page/17 (accessed on 20 January 2019).

48. Politika, Sjenica Cheese-National Heritage Seeks Market. Available online: http:/ /www.politika.rs/sr / clanak/366635/Sjenicki-sir-nacionalno-blago-u-potrazi-za-trzistem (accessed on 26 July 2018).

49. European Food Safety Authority_EFSA, Novel and Traditional Food: Guidance Finalised. Available online: https:/ / www.efsa.europa.eu/en/press/news/161110 (accessed on 15 August 2018).

50. Euromonitor, Dairy in Western Europe. Available online: http://www.euromonitor.com/dairy-in-westerneurope/report (accessed on 22 June 2018).

51. PM Food \& Dairy Consulting, The World Cheese Market Report 2000-2020. Available online: http:/ / www. pmfood.dk/upl/9735/WCMINFORMATION.pdf (accessed on 22 June 2018).

52. De-Magistris, T.; Gracia, A. Consumers' willingness to pay for light, organic and PDO cheese: An experimental auction approach. Br. Food J. 2016, 118, 560-571. [CrossRef]

53. Garabal, J.I. Biodiversity and the survival of autochthonous fermented products. Int. Microbiol. 2007, 10, 1-3. [CrossRef] [PubMed]

54. Roininen, K.; Lähteenmäki, L.; Tuorila, H. Quantification of consumer attitudes to health and hedonic characteristics of foods. Appetite 1999, 33, 71-88. [CrossRef] [PubMed]

55. Grunert, K.G.; Aachmann, K. Consumer reactions to the use of EU quality labels on food products: A review of the literature. Food Control 2016, 59, 178-187. [CrossRef]

56. Giraud, G.; Amblard, C.; Thiel, E.; Zaouche-Laniau, M.; Stojanović, Ž.; Pohar, J.; Butigan, R.; Cvetković, M.; Mugosa, B.; Kendrovski, V.; et al. A cross-cultural segmentation of western Balkan consumers: Focus on preferences toward traditional fresh cow cheese. J. Sci. Food Agric. 2013, 93, 3464-3472. [CrossRef] [PubMed]

57. Sayer, A. Method in Social Science: A Realist Approach; Routledge: London, UK; New York, NY, USA, 1992; ISBN 0415076072.

58. Saunders, M.; Lewis, P.; Thornhill, A. Research Methods for Business Students, 5th ed.; Prentice Hall: Essex, UK, 2009; ISBN 0273716867.

59. Guba, E.E.; Lincoln, Y.S. Competing paradigms in qualitative research. In Handbook of Qualitative Research; Denzin, N.K., Lincoln, Y.S., Eds.; Sage: London, UK, 1994; pp. 105-117. ISBN 0803946791.

60. Levi-Faur, D. Comparative research designs in the study of regulation: How to increase the number of cases without compromising the strengths of case-oriented analysis. In The Politics of Regulation; Jacint, J., Levi-Faur, D., Eds.; Edward Elgar Publishing: Cheltenham, UK, 2004; pp. 177-199.

61. Levi-Faur, D. A Question of Size? In Innovative Comparative Methods for Policy Analysis; Rihoux, B., Grimm, H., Eds.; Springer: Boston, MA, USA, 2006; pp. 43-66.

62. Wagner, D.; Suchan, C.; Leunig, B.; Frank, J. Towards the analysis of information systems flexibility: Proposition of a method. In Proceedings of the 10th International Conference on Wirtschaftsinformatik, Zurich, Switzerland, 16-18 February 2011; pp. 808-817.

63. Verma, S.; Bhattacharyya, S.S. Perceived strategic value-based adoption of Big Data Analytics in emerging economy: A qualitative approach for Indian firms. J. Enterp. Inf. Manag. 2017, 30, 354-382. [CrossRef]

64. Siu, W.S.; Kirby, D.A. Research into small firm marketing: A contextual stepwise approach. Qual. Mark. Res. 1999, 2, 135-146. [CrossRef]

65. Bryman, A. Integrating quantitative and qualitative research: How is it done? Qual. Res. 2006, 6, 97-113. [CrossRef]

66. Thomas, P.Y. Towards Developing a Web-Based Blended Learning Environment at the University of Botswana. Ph.D. Thesis, University of South Africa, Pretoria, South Africa, 2010.

67. Gray, D.E. Doing Research in the Real World; SAGE Publications: London, UK, 2004; ISBN 9781847873378.

68. David, M.; Sutton, C.D. Social Research the Basics; SAGE Publications: London, UK, 2004; ISBN 0761973664.

69. Mentzer, J.T.; DeWitt, W.; Keebler, J.S.; Min, S.; Nix, N.W.; Smith, C.D.; Zacharia, Z.G. Defining supply chain management. J. Bus. Logist. 2001, 22, 1-25. [CrossRef]

70. Pučètaitè, R.; Lämsä, A.M. Developing organizational trust through advancement of employees' work ethic in a post-socialist context. J. Bus. Ethics 2008, 82, 325-337. [CrossRef]

71. Rose-Ackerman, S. Trust and honesty in post-socialist societies. Kyklos 2001, 54, 415-443. [CrossRef] 
72. Hagedorn, K. Post-Socialist Farmers' Cooperatives in Central and Eastern Europe. Ann. Public Coop. Econ. 2014, 85, 555-577. [CrossRef]

73. Vidović, D.; Rakin, D. Social Entrepreneurship and the Revitalization of the Cooperative sector: Emergence of Social Cooperatives in Croatia and Serbia. In Social Enterprise Developments in the Balkans; Baglioni, S., Roy, M., Micaela, M., Srbijanko, J.K., Bashevska, M., Eds.; Reactor-Research in Action: Skoplje, Republic of Macedonia, 2017; pp. 7-22, ISBN 978-608-4684-24-4.

74. Kirmani, A.; Rao, A.R. No pain, no gain: A critical review of the literature on signaling unobservable product quality. J. Mark. 2000, 64, 66-79. [CrossRef]

(C) 2019 by the author. Licensee MDPI, Basel, Switzerland. This article is an open access article distributed under the terms and conditions of the Creative Commons Attribution (CC BY) license (http://creativecommons.org/licenses/by/4.0/). 